\title{
Detection of human herpesvirus 8 by quantitative polymerase chain reaction: development and standardisation of methods
}

David J Speicher ${ }^{1,2^{*}}$ and Newell W Johnson 2,3

\begin{abstract}
Background: Human herpesvirus 8 (HHV-8), the aetiological agent of Kaposi's sarcoma (KS), multicentric Castleman's disease (MCD), and primary effusion lymphoma (PEL) is rare in Australia, but endemic in Sub-Saharan Africa, parts of South-east Asia and Oceania. While the treatment of external KS lesions can be monitored by clinical observation, the internal lesions of KS, MCD and PEL require extensive and expensive internal imaging, or autopsy. In patients with MCD and PEL, if HHV-8 viraemia is not reduced quickly, 50\% die within 24 months. HHV-8 qPCR is a valuable tool for monitoring HHV-8 viraemia, but is not available in many parts of the world, including those with high prevalence of $\mathrm{KS}$ and HHV-8.
\end{abstract}

Methods: A new molecular facility with stringent three-phase workflow was established, adhering to NPAAC and CLSI guidelines. Three fully validated quantitative assays were developed: two for detection and quantification of HHV-8; one for GAPDH, necessary for normalisation of viral loads in tissue and peripheral blood.

Results: The HHV-8 ORF73 and ORF26 qPCR assays were 100\% specific. All qPCR assays, displayed a broad dynamic range $\left(10^{2}\right.$ to $10^{10}$ copies/ $\mu \mathrm{L}$ TE Buffer) with a limit of detection of $4.85 \times 10^{3}, 5.61 \times 10^{2}$, and $2.59 \times 10^{2}$ copies/ $\mu \mathrm{L} \mathrm{TE}$ Buffer and a limit of quantification of $4.85 \times 10^{3}, 3.01 \times 10^{2}$, and $1.38 \times 10^{2}$ copies/ML TE Buffer for HHV-8 ORF73, HHV-8 ORF26, and GAPDH respectively.

The assays were tested on a panel of $35 \mathrm{KS}$ biopsies from Queensland. All were HHV-8 qPCR positive with average viral load of $2.96 \times 10^{5} \mathrm{HHV}-8$ copies/ $\mu \mathrm{L}$ DNA extract (range: $4.37 \times 10^{3}$ to $1.47 \times 10^{6}$ copies/ $\mu \mathrm{L}$ DNA extract): When normalised these equate to an average viral load of $2.44 \times 10^{4} \mathrm{HHV}-8$ copies $/ 10^{3}$ cells (range: $2.20 \times 10^{2}$ to $7.38 \times 10^{5}$ HHV-8 copies $/ 10^{3}$ cells).

Conclusions: These are the first fully optimised, validated and MIQE compliant HHV-8 qPCR assays established in Australia. They worked well for qualitative detection of HHV-8 in archival tissue, and are well-suited for quantitative detection in whole blood. They are now available for research, for clinical diagnosis of HHV-8 infection, and for monitoring treatment efficacy.

Keywords: HHV-8, Kaposi's sarcoma, Human herpesvirus 8, Molecular diagnostics, Laboratory establishment

\footnotetext{
* Correspondence: d.speicher@griffith.edu.au

${ }^{1}$ School of Dentistry and Oral Health, Griffith University, Queensland, Australia ${ }^{2}$ Molecular Basis of Disease Research Program, Griffith Health Institute, Griffith University, Queensland, Australia

Full list of author information is available at the end of the article
} 


\section{Background}

Human herpesvirus 8 (HHV-8), the aetiological agent of Kaposi's sarcoma (KS), an AIDS-defining condition, multicentric Castleman's disease (MCD) and primary effusion lymphoma (PEL) has been extensively characterized worldwide, but largely overlooked in Australia as the introduction of antiretroviral therapy in 1995-96 greatly reduced the incidence of KS. Australian researchers have looked briefly at the risk factors associated with the sexual transmission of HHV-8 [1,2], at detection methods [3,4], and at the genotyping of a few HHV-8 isolates [5]. Despite the low prevalence of HHV-8 associated disease in Australia, since 2007, 25 new HHV-8 PCR positive patients have been identified in Queensland, including one child aged just 3 years. In 2011, the first case of KS for 10 years was recognised at the Gold Coast Sexual Health Clinic, and a further eight cases of HHV-8 disease were also recognised clinically in the Brisbane area suggesting the possible re-emergence of HHV-8-related diseases and/or increased clinical recognition and testing. In Australia, most major anatomical pathology laboratories perform HHV-8 immunohistochemistry, but validated molecular assays are uncommon. HHV-8 nested PCR is performed at PathWest Laboratory Medicine, QEII Hospital, in Perth, Western Australia (the referral laboratory for Queensland Health), while real-time PCR (rtPCR) is performed at the Victorian Infectious Diseases Reference Laboratory (VIDRL) in Melbourne, Victoria and the South Eastern Area Laboratory Services (SEALS), Prince of Wales Hospital in Sydney, New South Wales. None of these laboratories perform quantitative PCR (qPCR) to monitor viral loads and treatment efficacy: This is of concern because, while the treatment of superficial KS can be monitored by clinical observation, both MCD and PEL require more extensive and expensive internal imaging, notably with computed axial tomography (CAT), magnetic resonance imaging (MRI) or positron emission tomography (PET) scans.

As the first research laboratory in Australia specialising in the detection and characterisation of HHV-8, our first objective was to establish fully validated HHV-8 qPCR assays to aid in the cost-effective and timely diagnosis of HHV-8 associated diseases, and to accurately monitor treatment regimes and save costs of other complex monitoring methods. Even with the high sensitivity of PCR, most asymptomatic patients are HHV-8 negative in this test, making PCR an ideal technique to monitor current infections [6-8]. This report provides details to assist with overcoming many of the challenges associated with establishing a new quantitative assay including: laboratory establishment, choice of positive and negative controls, and assay optimisation and validation for HHV-8 ORF73, HHV-8 ORF26, and the human reference gene glyceraldehyde 3phosphate dehydrogenase (GAPDH) qPCR. These assays were used in an attempt to quantify HHV-8 in lesional biopsies but, due to issues with normalisation, are better suited for viral detection and monitoring of treatment by detecting and quantifying HHV-8 viraemia in peripheral blood mononuclear cells (PBMC).

\section{Methods \\ Body cavity-based lymphoma (BCBL)-1 cell line harbouring latent HHV-8}

BCBL-1 cells, an HHV-8 positive EBV negative cell line, were seeded at $3-5 \times 10^{5}$ cells $/ \mathrm{mL}$ (counted using trypan blue), and cultured in GIBCO $^{\circledR}$ RPMI-1640 supplemented with 2 mM GlutaMAX ${ }^{\mathrm{mm}}-\mathrm{I}$ and $25 \mathrm{mM}$ HEPES (Life Technologies $^{\mathrm{Tm}}$, Australia), as well as 10\% HIA-FBS, $55 \mu \mathrm{M} 2-$ mecaptoethanol, $1 \mathrm{mM}$ sodium pyruvate, and $100 \mathrm{mM}$ penicillin and streptomycin at $37^{\circ} \mathrm{C}$ in $5 \% \mathrm{CO}_{2}$ in a humidified atmosphere, and passaged $50 \%$ every $3-4$ days. Cell concentrations were maintained between $3 \times 10^{5}$ cells $/ \mathrm{mL}$ and $1 \times 10^{6}$ cells $/ \mathrm{mL}$. Cell stocks were kept frozen in liquid nitrogen in 10\% DMSO and 90\% HIAFBS, and were Mycoplasma free as determined by the PCR Mycoplasma Test Kit (AppliChem, USA). Viral and human genomic DNA were extracted from $100 \mu \mathrm{L}$ of cultured cells suspension diluted 1:1 with PBS using the DNeasy Blood and Tissue Kit (Qiagen, Australia) following the manufacturer's instructions, with a proteinase $\mathrm{K}$ digestion performed at $56^{\circ} \mathrm{C}$ for 10 minutes in a heating block. All samples were eluted in $100 \mu \mathrm{L}$ of Buffer AE to increase the final DNA concentration.

\section{Cloning of HHV-8 and GAPDH constructs for qPCR standards}

Amplicon containing -TA overhangs were produced by conventional PCR performed in a $20 \mu \mathrm{L}$ volume containing 10X ThermoPol Reaction Buffer (New England BioLabs ${ }^{\circledR}$ Inc., Australia), $0.4 \mathrm{mM}$ deoxyribonucleotide triphosphate (dNTP), $0.2 \mu \mathrm{M}$ primers (GeneWorks, Australia), 0.24 U/ $\mu \mathrm{L}$ Taq DNA polymerase (New England BioLabs ${ }^{\circledR}$ Inc., Australia) and $2 \mu \mathrm{L}$ of nucleic acid extract (DNeasy Blood and Tissue Kit, Qiagen, Australia). The HHV-8 and GAPDH targets were amplified from DNA purified from BCBL- 1 cells. PCR consisted of 45 cycles of amplification $\left(20\right.$ seconds at $95^{\circ} \mathrm{C} ; 30$ seconds at $58^{\circ} \mathrm{C}, 30$ seconds at $72^{\circ} \mathrm{C}$ ), followed by a 15 minute extension step at $72^{\circ} \mathrm{C}$ in an iCycler Thermal Cycler (Bio-Rad, Australia). The entire $20 \mu \mathrm{L}$ reaction was mixed with loading buffer (MO BIO Laboratories, Inc., Australia) and placed in a well of $2 \% \mathrm{w} / \mathrm{v}$ agarose low EEO (AppliChem, USA) containing SYBR $^{\circledR}$ Safe DNA Gel Stain $(10,000 \mathrm{X}$ concentrate in DMSO; Life Technologies ${ }^{\mathrm{TM}}$, Australia) in TAE buffer (0.04 M Tris-acetate, $1 \mathrm{mM}$ EDTA) and analysed by agarose gel electrophoresis. A molecular weight marker (DMW-100M, GeneWorks, Australia) was added as a reference. Agarose gels were run at 
$120 \mathrm{~V}$ for 30 minutes, visualised by exposure to blue light (VersaDoc ${ }^{\text {TM }}$ Imaging System 4000 MP, Bio-Rad, Australia) and examined with Quality One ${ }^{\circledR}$ V.6.3 1-D Analysis Software (Bio-Rad, Australia). Amplicon of the correct molecular weight was gel purified (QIAquick Gel Extraction Kit, Qiagen, Australia) and the eluted DNA quantified on the NanoDrop ${ }^{\circledR}$ ND-1000 Spectrophotometer (ThermoFisher Scientific, Australia).

Plasmid constructs were formed by ligating purified PCR amplicon into pGEM ${ }^{\circledR}-\mathrm{T}$ Easy (Promega, USA) at a concentration of 3:1 respectively. The ligation reaction contained 2X Quick Ligation Reaction buffer and Quick T4 DNA Ligase (New England BioLabs ${ }^{\circledR}$ Inc., Australia) and was performed in a $20 \mu \mathrm{L}$ volume at $25^{\circ} \mathrm{C}$ for $5 \mathrm{~min}$ utes. The construct was concentrated and salts were removed by mixing $1 \mathrm{~mL}$ butanol with $10 \mu \mathrm{L}$ ligation mixture and then centrifuging at 14,000 $x g$ for one minute, decanting the butanol and then drying in a Concentrator Plus (Eppendorf South Pacific, Australia) for 5 minutes. The construct was resuspended in $4 \mu \mathrm{L}$ of $\mathrm{dH}_{2} \mathrm{O}$, mixed with $30 \mu \mathrm{L}$ of competent $\mathrm{DH} 5 \alpha$ Escherichia coli, and incubated on ice for 5 minutes. Transformation was performed in a $2 \mathrm{~mm}$ cuvette by electroporation at $2.5 \mathrm{KV}, 200 \Omega$, and $25 \mu \mathrm{F}$ with the Gene Pulser Xcell ${ }^{\text {TM }}$ System (Bio-Rad, Australia). Transformants were slowly shaken while incubated at $37^{\circ} \mathrm{C}$ for 40 minutes in $500 \mu \mathrm{L}$ SOC broth (2\% tryptone, $0.5 \%$ yeast extract, $10 \mathrm{mM} \mathrm{NaCl}, 2.5 \mathrm{mM} \mathrm{KCl}, 10 \mathrm{mM}$ $\mathrm{MgCl}_{2}, 20 \mathrm{mM}$ glucose), plated out on $2 \mathrm{YT}$ agar containing $50 \mu \mathrm{g} / \mathrm{mL}$ ampicillin, and then grown overnight at $37^{\circ} \mathrm{C}$. The resulting constructs were named following the convention $\mathrm{PGEM}^{\circledR}-\mathrm{T} / \mathrm{XXXX}$, with the XXXX corresponding to the HHV-8 and human reference gene such as pGEM ${ }^{\circledR}-\mathrm{T} / \mathrm{ORF73.}$

Colonies with constructs containing the gene of interest (GOI) were selected by colony PCR screening of the white colonies as follows: constructs were released from bacterial cells by boiling for 2 minutes in $15 \mu \mathrm{L} d \mathrm{H}_{2} \mathrm{O}$ and then examined by PCR using the M-13 universal sequencing primers (USP) [5'-GTAAAACGACGGCCA GT-3'] and reverse sequencing primers (RSP) [5'-AT TTCACACAGGAAACAGCTATGAC-3'] [9]. PCR was subsequently performed in a $20 \mu \mathrm{L}$ volume containing 10X ThermoPol Reaction Buffer (New England BioLabs ${ }^{\circledR}$ Inc., Australia), $0.4 \mathrm{mM}$ dNTP, $0.2 \mu \mathrm{M}$ primers (GeneWorks, Australia), 0.24 U/ $\mu \mathrm{L}$ Taq DNA polymerase (New England BioLabs ${ }^{\circledR}$ Inc., Australia). Amplicon were produced by conventional PCR consisting of 25 cycles of amplification (60 seconds at $94^{\circ} \mathrm{C}$; 90 seconds at $42^{\circ} \mathrm{C}$; 60 seconds at $72^{\circ} \mathrm{C}$ ) and then examined by agarose gel electrophoresis as previously described.

Colonies containing the desired construct were grown overnight at $37^{\circ} \mathrm{C}$ in $3 \mathrm{~mL}$ of $2 \mathrm{YT}$ broth containing $50 \mu \mathrm{g} / \mathrm{mL}$ ampicillin and catalogued as glycerol stocks
(800 $\mu \mathrm{L}$ culture in $200 \mu \mathrm{L} 80 \%$ glycerol). Plasmid DNA was extracted from the cultures with FastPlasmid ${ }^{\mathrm{Tm}}$ Mini Kit (5 PRIME, Australia), their concentration determined by NanoDrop and diluted to $30 \mathrm{ng} / \mu \mathrm{L}$. Constructs were catalogued at $-80^{\circ} \mathrm{C}$ to minimise damage from freeze/ thaw cycles, but working stocks were stored at $4^{\circ} \mathrm{C}$ [10]. Nucleotide sequencing was performed on both strands of the GOI within the $\mathrm{pGEM}^{\circledR}$-T Easy using the ABI PRISM $^{\mathrm{TM}}$ BigDye cycle sequencing kit (Perkin Elmer Applied Biosystems Division, USA) and the Applied Biosystems 3130xl capillary electrophoresis genetic analyser (Perkin Elmer Applied Biosystems Division, USA) at the Griffith University DNA Sequencing Facility (GUDSF, Griffith University (NATA accreditation \#14814)). Nucleotide sequence alignments were analysed using BioEdit Sequence Alignment Editor ${ }^{\circledR}$ v7.0.5.2 [11] against known sequences available in GenBank.

\section{Optimisation and validation of quantitative PCR assays}

All qPCR assays were fully optimised and validated for the detection of HHV-8 as outlined by the Australian National Pathology Accreditation Advisory Council (NPAAC), Clinical and Laboratory Standards Institute (CLSI), [formerly known as the National Committee for Clinical Laboratory Standards (NCCLS)] and by the Minimum Information for Publication of Quantitative Real-Time PCR Experiments (MIQE) Guidelines, using both cloned constructs and DNA extracted from BCBL-1 cells as the reference material [10,12-14]. The optimal primer annealing temperature $\left(\mathrm{T}_{\mathrm{M}}\right)$ was determined on BCBL-1 DNA extracts in duplicate with a temperature gradient from $55.0^{\circ} \mathrm{C}$ to $63.0^{\circ} \mathrm{C}$ on an iQ5 Real-Time PCR Detection System (Bio-Rad, Australia) using the QuantiFast SYBR Green PCR Kit (Qiagen, Australia). The primer concentration was determined in duplicate using a primer matrix on both sense and anti-sense primers so that the final concentration of the primers in the reaction mixture are tested from $50 \mathrm{nM}$ to $900 \mathrm{nM}$ $[15,16]$. The concentrations of the dual-labelled hydrolysis probes were determined by testing a range between 25 $\mathrm{nM}$ and $300 \mathrm{nM}$. The probes were tested for integrity by running negative controls of just water and probe at low and high probe concentrations. The optimal $\mathrm{T}_{\mathrm{M}}$, primer concentration, and dual-labelled hydrolysis probe concentrations were determined by the amplification curve with the best shape and lowest cycle of quantification $(\mathrm{Cq})$.

The accuracy, imprecision, PCR efficiency, linearity, measurable range, and repeatability, of the $\mathrm{qPCR}$ assays were validated using calibration curves [10-fold serial dilutions of the cloned constructs in TE Buffer (prepared in-house: $10 \mathrm{mM}$ Tris-HCl, $1 \mathrm{mM}$ EDTA, pH 8.0)]. Calibration curves were prepared fresh and examined in triplicate by qPCR on a Rotor-Gene Q (Qiagen, Australia). The actual copy number, determined by qPCR (y-axis), 
was compared to the calculated copy number ( $\mathrm{x}$-axis) graphically on Microsoft Excel with the standard deviations shown in vertical error bars and examined by linear regression analysis for linearity $\left(\mathrm{R}^{2}\right)$, slope, intercept, and standard deviation of the residuals $[17,18]$. The calculated copy number was determined from the plasmid concentration determined via NanoDrop with the following formulae:

1. Molecular Weight (MW) (plasmid) in $\mathrm{g} / \mathrm{mol}=$ plasmid length (bp) x $660 \mathrm{Da}$

2. Plasmid $\left(\right.$ copies/g) $=$ Avogadro's Number $\left(6.02 \times 10^{23}\right) /$ MW(plasmid)

3. [Plasmid] in $\mathrm{mol} / \mathrm{L}=$ [plasmid] as per NanoDrop $(\mathrm{g} / \mathrm{L})$ x MW (plasmid)

4. Plasmid $($ copies $/ \mu \mathrm{L})=[$ plasmid $] \mathrm{mol} / \mu \mathrm{L} \times \mathrm{MW}$ (plasmid) x Plasmid (copies/g)

The calibration curve was rejected if the qPCR efficiency was outside the range of $95-105 \%$ (5\% variance from $100 \%)$ and linearity $\left(R^{2}\right)$ was $<0.9800$. The measurable range of detection was determined by the linear region of the standard curve. The repeatability of the assay was measured by running the standard curve in triplicate over a 20 day period and comparing the copy numbers. The analytical sensitivity, determined as the limit of detection (LOD), and the limit of quantification (LOQ), were determined from a calibration curve serially diluted 2-fold. These calibration curves were produced in triplicate with the quantitative standard of highest concentration diluted from the quantitative standard of the calibration curve serially diluted 10 -fold, which was 10 fold greater than the minimum detectible dilution. Each standard was examined three times per day for eight days [19]. The LOD was determined at the $95 \%$ confidence interval (CI) as being the point where no less than 23/24 samples were positive, whereas the LOQ was determined as the lowest concentration where the actual and calculated concentrations were nearly identical $[19,20]$. Since this project was performed on a single PCR machine by one operator, the robustness of the assay, although desired [21], could not be determined. Additionally, it would be ideal to include a comparative evaluation of this method against reference methods [10], but no such method is available in Australia.

The specificity of the HHV-8 qPCR assays were determined by running the assays against a panel of all HHV and were deemed specific if the assay only amplified the HHV-8 sample.

\section{Quantitative PCR assays}

qPCR assays were designed to amplify a 142 bp and a 234 bp fragment of the HHV-8 ORF73 and ORF26 respectively as well as a 104 bp fragment of GAPDH from previously published primer and dual-labelled hydrolysis probe sequences (Table 1) [6,22,23]. qPCR assays were set up manually in $0.1 \mathrm{~mL}$ strip tubes (Qiagen, Australia; Cat\#:981103) in a $20 \mu \mathrm{L}$ volume using the QuantiFast ${ }^{\mathrm{rm}}$ Probe PCR + ROX Vial Kit (Qiagen, Australia) (containing HotStarTaq ${ }^{\circledR}$ Plus DNA Polymerase, dNTP mix, and QuantiFast $^{\text {tM }}$ PCR buffer), $0.2 \mu \mathrm{M}$ primers, $0.1 \mathrm{mM}$ duallabelled hydrolysis probe (Purity: HPLC; GeneWorks, Australia), and $2 \mu \mathrm{L}$ of nucleic acid extract. The qPCR reaction was performed on a Rotor-Gene $Q$ starting with a five minute polymerase activation step at $95^{\circ} \mathrm{C}$, followed by 45 cycles of amplification ( 5 seconds denaturation at $95^{\circ} \mathrm{C} ; 30$ seconds annealing/extension at $58^{\circ} \mathrm{C}$ ). qPCR results were reported in "copies/ $\mu \mathrm{L}$ TE Buffer" for the calibration curves and "copies/ $\mu \mathrm{L}$ DNA extract" for the clinical isolates. For clinical samples the average

Table 1 Primers and probes used for HHV-8 and GAPDH qPCR assays

\begin{tabular}{|c|c|c|c|c|c|}
\hline Assay & Primers/Probe & Sequence $\left(5^{\prime}-3^{\prime}\right)$ & $\begin{array}{l}\text { Nucleotide } \\
\text { position* }\end{array}$ & $\begin{array}{l}\text { Amplicon } \\
\text { length }\end{array}$ & Reference \\
\hline \multicolumn{6}{|c|}{ Quantitative PCR Assays for HHV-8 } \\
\hline \multirow[t]{3}{*}{ HHV-8 ORF73 } & HHV8_73_01.1 & GGTGATGTTCTGAGTACATAGCGG & $124,326-124,349$ & $142 \mathrm{bp}$ & Lallemand et al., 2000 \\
\hline & HHV8_73_02.1 & CCGAGGACGAAATGGAAGTG & $124,467-124,448$ & & \\
\hline & HHV8_73_Pb1 & FAM-ACAAATTGCCAGTAGCCCACCAGGAGA-BHQ1 ${ }^{\varepsilon}$ & $124,421-124,395$ & & \\
\hline \multirow[t]{3}{*}{ HHV-8 ORF26 } & HHV8_26_01.1 & AGCCGAAAGGATTCCACCATT & $47,287-47,304$ & $234 \mathrm{bp}$ & Hammock et al., 2005 \\
\hline & HHV8_26_02.1 & TCCGTGTTGTCTACGTCCAGA & $47,519-47,499$ & & \\
\hline & HHV8_26_Pb.3 & FAM-TGCAGCAGYTGTTGGTGTACCACAT-BHQ $1^{\xi}$ & $47,378-47,402$ & & \\
\hline \multicolumn{6}{|c|}{ Quantitative PCR Assays for Normalisation to Cell Counts } \\
\hline \multirow[t]{3}{*}{ GAPDH } & GAPDH_01.1 & GCTCCCTCTTTCTTTGCAGCAAT & $7.800-7,822$ & $104 \mathrm{bp}$ & Asahi-Ozaki et al., 2006 \\
\hline & GAPDH_02.1 & TACCATGAGTCCTTCCACGATAC & $7,903-7,881$ & & \\
\hline & GAPDH_Pb1 & FAM-TCCTGCACCACCAACTGCTTAGCACC-BHQ $1^{\varepsilon}$ & $7.826-7,851$ & & \\
\hline
\end{tabular}

*Nucleotide position was determined from the reference sequences [GenBank:NC_003409] for HHV-8 and [GenBank:NG_007073.2] for GAPDH.

${ }^{\varepsilon}$ Probes had $5^{\prime}$ terminus labeled with a FAM (6-carboxy-fluorescein) fluorophore and $3^{\prime}$ terminus labeled with BHQ-1 (Black Hole Quencher ${ }^{\circledR}$ ). 
viral loads were determined from both the HHV-8 ORF73 and HHV-8 ORF26 qPCR assays and then normalized to cell copy number, based on GAPDH results (there are two copies of GAPDH/cell) and then reported as HHV- 8 copies $/ 10^{3}$ cells.

\section{Controls and sample population}

Analytical positive controls, and a range of negative controls (analytical, no-template control (NTC) and clinically negative tissues) were included on each PCR run to ensure accuracy of results. BCBL-1 extracts at a concentration $\sim 10^{4}$ (10-fold higher than the assay LOD) and a 10-fold standard curve run in singular were included in each run to ensure PCR efficiency, linearity and that Cq values were consistent between runs [10]. Negative controls on each run included one sample from an HHV-8 negative oral squamous cell carcinoma biopsy and two to three NTC samples per run, and positioned at the front, middle and end of each sample set [10]. A PCR run was discarded due to inaccuracy if any of the following criteria occurred: (i) PCR efficiency differed by $5 \%$ of the validated efficiency, (ii) the $\mathrm{Cq}$ value of the positive control differed by more than 1, (ii) any of the negative controls were positive so that a definite sample concentration could be determined, or if (iv) the standard curve was not linear $\left(R^{2}<0.98000\right)$.

The assays were tested on an opportunistic collection of KS archival lesions from various Queensland hospitals retrospectively following ethical clearance (Griffith University Human Research Ethics Committee (HREC) (DOH/05/07/HREC), RBWH HREC (\#2007/089), PAH HREC (\#2007/117), Townsville Hospital HREC (\#39/07), Gold Coast Hospital HREC (\#200750), the DirectorGeneral of Queensland Health (BR033835, 000784-3), and Clinical and Statewide Services (\#128)). The sample population consisted of 35 biopsies of KS lesions from 24 patients presenting between 2004 and 2011: Eight biopsies were from five HIV-negative patients (males:females 3:2) with a mean age of 83.05 years (range: $78.94-88.60$ years) while 39 biopsies were from 31 HIV-positive males with a mean age of 43.76 years (range: $28.16-66.28$ years).

All clinical samples were examined by both HHV-8 qPCR assays, to determine the viral load with accuracy, and to avoid the risk of false positives and negatives $[10,24]$. If a sample yielded a negative result it was reexamined with GAPDH to examine for inhibition, to determine that adequate DNA was in the sample and to verify that DNA had been extracted [10]. If a sample yielded a positive result but the concentration was below the LOD, it was repeated. If the repeated test showed the sample was negative or yielded a second positive result that was below the LOD, it was labelled as "not detected". If a sample was strongly positive by one of the HHV-8 qPCR assays, but negative in the other assay the sample was repeated in triplicate with the other assay. If the repeat testing showed that the sample was repeatedly negative in only one of the assays then it was recorded, accordingly: e.g. HHV-8 ORF73 positive, HHV-8 ORF26 negative.

\section{Results and discussion}

Establishing an entirely new molecular laboratory is difficult, complex and time consuming: especially for work with viruses that are rare in a particular geographical area. Whether designed for research only or for clinical diagnostics, in order to produce quality results a molecular laboratory must have stringent workflows based on the NPAAC guidelines [10].

PCR contamination was minimized by implementing basic laboratory practices, chemical barriers, strict sterilization practices, and a strict unidirectional PCR workflow with three physically separate areas for: preparation of reagents; DNA extraction and template adding; and PCR amplification and post-PCR manipulations [10,25-27]. However, due to space constraints, DNA extraction was performed on a bench in the main laboratory with template added to the PCR reaction mixture in a Top-safe 1.2 biological safety cabinet class II (BSCII) (Bio-Cabinets Australia Pty, Australia). Each area contained its own dedicated equipment, reagents and personal protective equipment [10]. As rtPCR was performed as a sealed system, amplification was also performed in the main laboratory with the tubes only opened in the contained post-amplification area [10].

Carryover contamination was prevented by the strict implementation of the unidirectional flow from preamplification to post-amplification areas, with only sealed tubes and racks travelling down the workflow [10]. If anything needed to be re-used and go against the unidirectional flow, such as PCR racks or bottles, they were decontaminated overnight in a 1:100 dilution of Trigene $^{\circledR}$ Advance (MediChem International Ltd, UK) before returning to the pre-amplification area [10]. Cross-contamination was prevented from all DNA extractions and template handling by wiping down the laboratory bench and BSCII with a 1:20 dilution of Trigene $^{\circledR}$ Advance followed by UV radiation for 20 minutes. Trigene ${ }^{\circledR}$ Advance was used as a spray at 1:20 and 1:100 to soak used racks overnight due to its cost effectiveness and ability to degrade DNA.

All molecular assays require clinical and analytical, positive and negative controls. Obtaining positive control samples requires formal ethical clearance which can take many months. The usefulness of three types of molecular analytical positive controls were therefore reviewed: the uni-control method, synthetic controls (oligonucleotides and/or plasmids), and plasmids (imported or in-house) cloned from clinical isolates/cell lines (Table 2). Both the uni-control method [28] and the production of synthetic 
Table 2 Advantages and disadvantages of three types of molecular analytical positive controls

\begin{tabular}{|c|c|c|c|c|}
\hline \multicolumn{2}{|c|}{ Positive control } & Advantages & Disadvantages & Reference \\
\hline \multirow{5}{*}{\multicolumn{2}{|c|}{ Uni-Control Method }} & - Can be used in the absence of wild-type control material & - Qualitative only not quantitative & \multirow[t]{5}{*}{ Whiley et al., 2010} \\
\hline & & - Reduced contamination & - Cannot be used for low viral loads & \\
\hline & & - DNA and RNA compatible & - Greater risk of primer dimer formation & \\
\hline & & \multirow[t]{2}{*}{ - Quick and simple method } & - Interim solution until wild-type material is available & \\
\hline & & & - Does not account for sequence variation in clinical material & \\
\hline \multicolumn{2}{|c|}{ Synthetic Controls } & - DNA and RNA compatible & - Synthetic oligonucleotides must be less than 200 bp & \multirow[t]{5}{*}{ Smith et al., 2006} \\
\hline \multirow{4}{*}{\multicolumn{2}{|c|}{ (Oligonucleotides and/or Plasmids) }} & - Reduced contamination (does not require cloning) & - Can be expensive if target is large & \\
\hline & & - Production of a synthetic oligonucleotide and clone into a plasmid & - Target sequence must be known & \\
\hline & & - No possibility of producing false-positives & \multirow[t]{2}{*}{ - Requires two separate control reactions (primer and probe) } & \\
\hline & & - Can be used for rtPCR and conventional PCR & & \\
\hline \multirow[t]{7}{*}{ Cloned Plasmids } & \multirow[t]{3}{*}{ Imported } & - Pre-made available (other labs or PlasmID repository) & • Requires shipping & \multirow[t]{3}{*}{ None } \\
\hline & & - Cost effective & - Difficult to distinguish contamination from clinical material & \\
\hline & & - Can be quantitative and qualitative & - Possible contamination & \\
\hline & \multirow[t]{4}{*}{ Produced "in-house" } & - Can be quantitative and qualitative & - Requires clinical material or live virus & \multirow[t]{4}{*}{ None } \\
\hline & & - Cost effective & - Requires cloning (time consuming) & \\
\hline & & \multirow[t]{2}{*}{ - Can easily be produced } & - Difficult to distinguish contamination from clinical material & \\
\hline & & & - Possible contamination & \\
\hline
\end{tabular}


controls [29] are good options, especially for the detection of rare or hazardous viruses, as their simplistic nature produces the desirable amplification target without the need for infectious virus. The uni-control method is a quick and simple procedure that attaches primer binding sites to the ends of PCR amplicon, but it is only an interim solution until wild-type material is available, and it cannot be used to determine viral loads or to detect low viral loads. The production of synthetic oligonucleotides, whole genes or viral open reading frames can be used for quantitative PCR assays, but can be expensive. While most primer/probe manufacturing companies can produce synthetic oligonucleotides these cannot be quantified, and the amplicon must be small ( $\leq 200 \mathrm{bp}$ ). As neither of these methods were ideal for our assays, nor are HHV-8 quantitative controls available within Australia, an attempt was made to import plasmids from international laboratories. While this can be cost effective, after facing difficulties with the Australian Quarantine and Inspection Service (AQIS) and several failed attempts to clone the plasmids, we acquired an $\mathrm{HHV}-8$ positive, EBVnegative body-cavity-based lymphoma cell line BCBL-1 [30]. These are freely available from the NIH AIDS Research and Reference Reagent Program, easy to propagate, and do not require ethical clearance. However, producing constructs via cloning has several inherent risks, especially cross-contamination due to the high copy numbers present: these were avoided by the strict unidirectional workflow.

All constructs were cloned from DNA purified from BCBL-1 cells, but diluted 1:1,000 in TE Buffer to yield a Cq between 20 and 25 for optimising primers and hydrolysis probes. The sequences of all pGEM-T/ORF73 [GenBank:JN613421] and pGEM-T/GAPDH [GenBank: JN613427-JN613429] constructs were identical to the published sequences [GenBank:NC_003409] and [GenBank: NG_007073.2] respectively (Additional files 1 and 2). The sequence of the pGEM-T/ORF26 construct [GenBank: JN613422-JN613426] had two conserved mismatches in all sequenced constructs; a $\mathrm{C} \rightarrow \mathrm{T}$ mismatch within the hydrolysis probe binding site: this required the probe sequence to be modified so that a pyrimidine (Y) would bind to both possible nucleotides (Additional file 3). The second mismatch was irrelevant. Using these constructs on a gradient block revealed the optimal $\mathrm{T}_{M}$ to be $58.0^{\circ} \mathrm{C}$ for the HHV-8 ORF73 and HHV-8 ORF26 rtPCR assays. The GAPDH rtPCR assay had two optimal $\mathrm{T}_{\mathrm{M}}, 58.0^{\circ} \mathrm{C}$ and $62.0^{\circ} \mathrm{C}$ : the lower temperature was used so that all three assays could be performed simultaneously. Using a primer concentration matrix and hydrolysis probe dilutions, the optimal concentrations were determined to be $200 \mathrm{nM}$ of both sense and anti-sense primers and $100 \mathrm{nM}$ of hydrolysis probe (Table 3 ).

Analytical specificity was tested in triplicate on a panel of DNA from all eight HHV. DNA was extracted from separate cultures of Vero cells infected with HSV-1 and HSV-2, cells carrying VZV, lymphoblastoid cell lines carrying EBV, SupT1 cells carrying HHV-7, and BCBL-1 carrying HHV-8. HCMV DNA was extracted from placental tissue known to be HCMV positive, and HHV-6 DNA was obtained from viral stocks. For all viruses, except HHV-8, the HHV-8 rtPCR assays yielded a negative result when examined via rtPCR and agarose gel electrophoresis, thus equating to an analytical specificity of $100 \%$ (Figure 1). This is unsurprising, considering the specificity of PCR and that all HHV-8 primer sequences were HHV-8 specific when analysed with NCBI's nucleotide-nucleotide basic local alignment search tool (BLASTn). GAPDH amplified most samples of the specificity panel due the virion being propagated from human cell lines, except the HHV-6 sample for which the agarose gel image showed possible primer-dimer formation.

Calibration curves produced a linear relationship for all qPCR assays from $10^{10}$ down to $10^{2}$ copies/ $\mu \mathrm{L}$ TE Buffer. Both HHV-8 and the GAPDH qPCR assays produced nearly perfect efficiency and linearity $\left(R^{2}\right)$ with

Table 3 Optimised conditions and PCR dynamics

\begin{tabular}{cccc}
\hline Assay & HHV-8 ORF73 & HHV-8 ORF26 & GAPDH \\
\hline Primer $\mathrm{T}_{\mathrm{M}}\left({ }^{\circ} \mathrm{C}\right)$ & 58.0 & 58.0 & 58.0 \\
Primer] & $200 \mathrm{nM}$, both primers & $200 \mathrm{nM}$, both primers & $200 \mathrm{nM}$, both primers \\
[Probe] & $100 \mathrm{nM}$ & $100 \mathrm{nM}$ & $100 \mathrm{nM}$ \\
Slope & $0.96842 \pm 0.02787$ & $0.97243 \pm 0.03028$ & $0.99701 \pm 0.02886$ \\
Intercept & $0.27100 \pm 0.20289$ & $0.21521 \pm 0.19569$ & $0.02605 \pm 0.19293$ \\
Linearity (R2) & 0.99424 & 0.99230 & 0.99334 \\
SD of Residuals & 0.21584 & 0.27500 & 0.26213 \\
Efficiency (\%) & 99.42 & 100.4 & 99.26 \\
Linear Range & $4.85 \mathrm{E}+03$ to $6.34 \mathrm{E}+10$ & $1.52 \mathrm{E}+02$ to $1.95 \mathrm{E}+10$ & $1.38 \mathrm{E}+02$ to $3.44 \mathrm{E}+10$ \\
LOD & $4.85 \mathrm{E}+03 \pm 3.02 \mathrm{E}+03$ & $5.61 \mathrm{E}+02 \pm 5.46 \mathrm{E}+02$ & $2.59 \mathrm{E}+02 \pm 2.48 \mathrm{E}+02$ \\
LOQ & $4.85 \mathrm{E}+03 \pm 3.02 \mathrm{E}+03$ & $3.01 \mathrm{E}+02 \pm 2.43 \mathrm{E}+02$ & $1.38 \mathrm{E}+02 \pm 1.17 \mathrm{E}+02$ \\
\hline
\end{tabular}



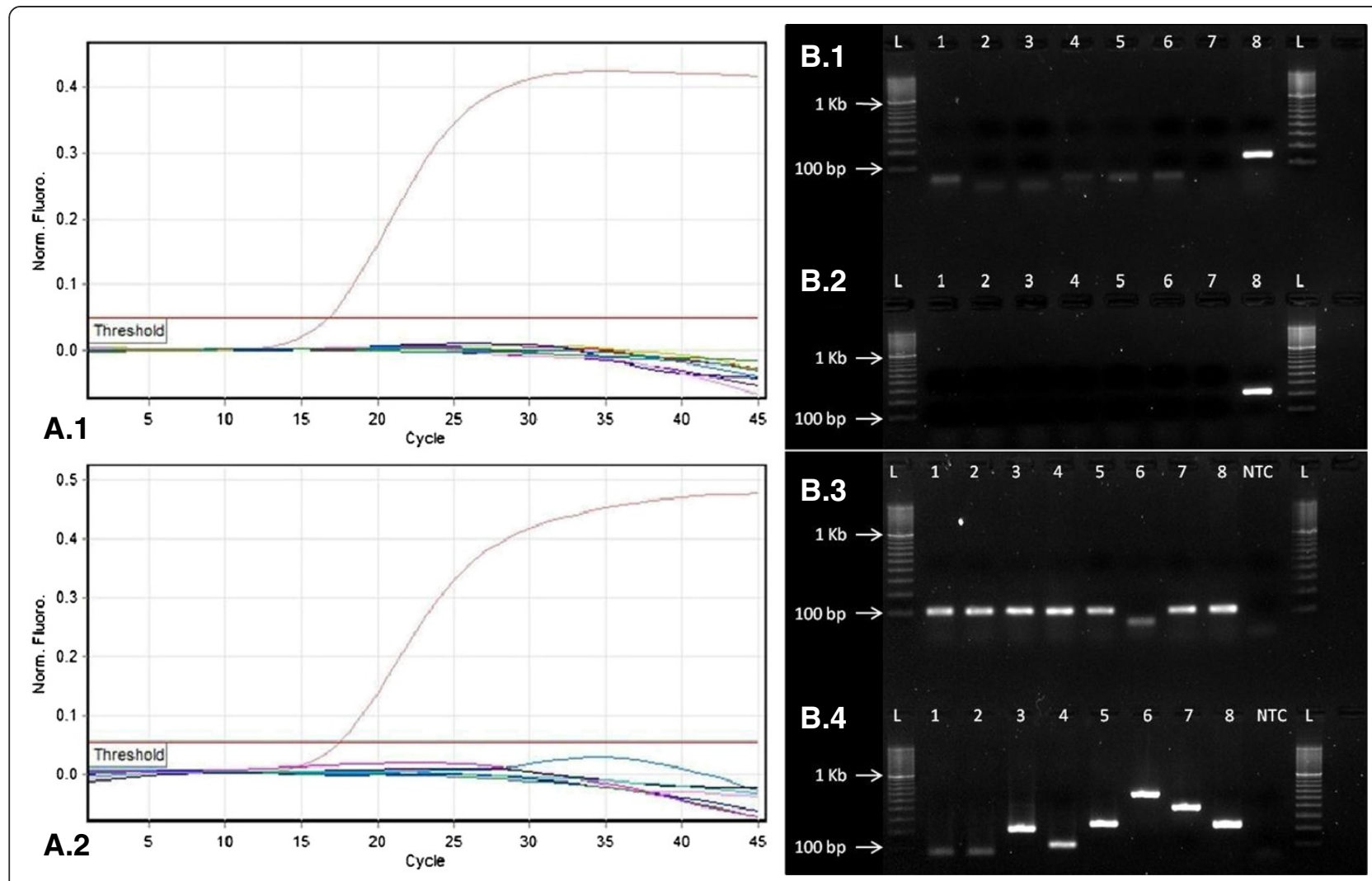

Figure 1 Specificity of the HHV-8 ORF73 and ORF26 qPCR Assays. Amplification curves (A) and agarose gel electrophoresis images (B) of the HHV-8 ORF73 (1) and ORF26 (2) assays tested against a panel of all eight HHV. The GAPDH PCR assay (B.3) was used as a DNA control as all samples were prepared from cell lines, except for HHV-6 (lane 6). Various primer sets were used to test HHV-1 to -8 (lanes 1 to 8 respectively). A 100 bp molecular weight marker was used as a reference.

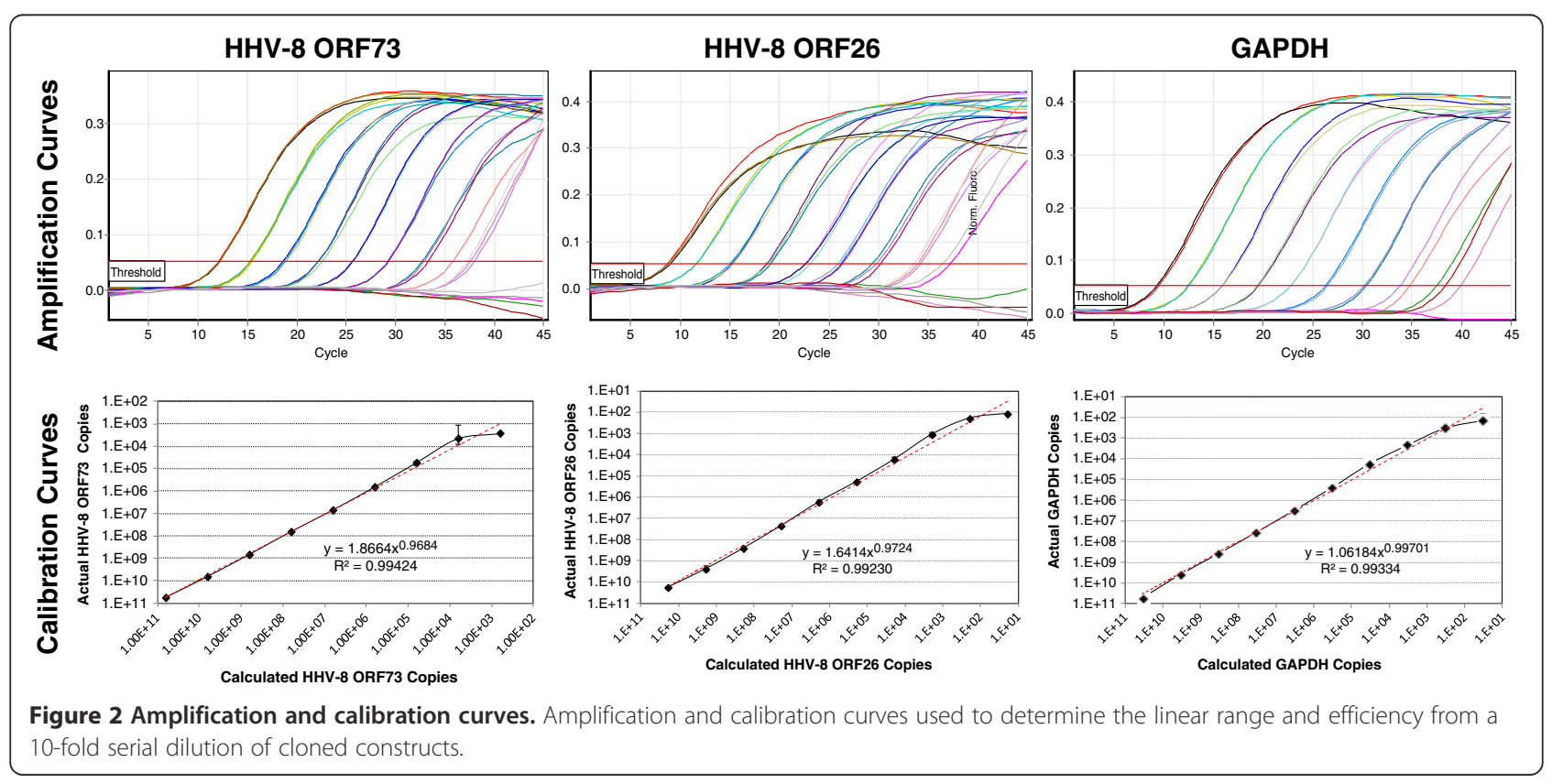


values of $99.40 \%$ and 0.99424 for the HHV-8 ORF73 qPCR assay, $100.40 \%$ and 0.99230 for the HHV-8 ORF26 qPCR assay, and $99.26 \%$ and 0.99334 for the GAPDH qPCR assay (Figure 2; Table 3). Calibration curves with 2 -fold serial dilutions displayed near perfect replicates from $6.43 \times 10^{4}$ to $8.04 \times 10^{3}$ copies/ $\mu \mathrm{L}$ TE Buffer (average coefficient of variation $(\mathrm{CV})=0.4088)$ and from $8.60 \times 10^{3}$ to $1.07 \times 10^{3}$ copies $/ \mu \mathrm{L}$ TE Buffer for the HHV-8 ORF73 and GAPDH assays respectively (Figure 3). The LOD and LOQ of the HHV-8 ORF73 qPCR assay were
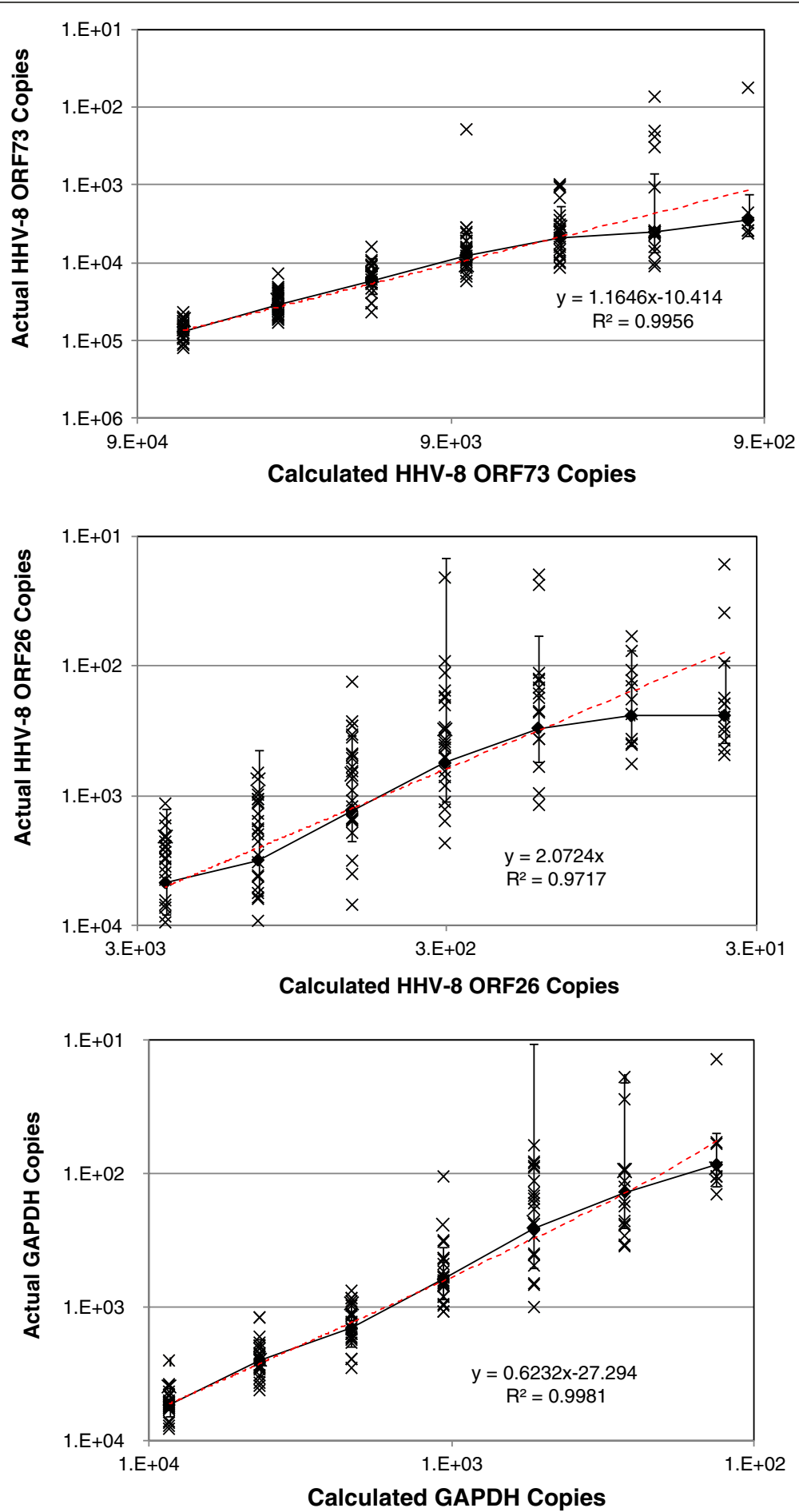

Figure 3 Assay sensitivity. Calibration curves using a $1 / 2$-serial dilution of cloned constructs to determine the limit of detection and limit of quantification of the HHV-8 ORF73, HHV-8 ORF26, and GAPDH qPCR assays. 
equivalent at $4.85 \times 10^{3} \pm 3.02 \times 10^{3}$ copies $/ \mu \mathrm{L}$ TE Buffer $(\mathrm{Cq}=37.44 \pm 1.05)$ whereas for the GAPDH $\mathrm{qPCR}$ assay the LOD was $2.59 \times 10^{2} \pm 2.48 \times 10^{2}$ copies $/ \mu \mathrm{L}$ TE Buffer $(\mathrm{Cq}=37.25 \pm 2.16)$ but the LOQ was $1.38 \times 10^{2} \pm 1.17 \times 10^{2}$ copies/ $\mu \mathrm{L}$ TE Buffer $(\mathrm{Cq}=38.52 \pm 2.70)$ (Table 3). The sensitivity (LOD and LOQ) of the HHV-8 ORF26 assay was 10-fold greater than the HHV-8 ORF73 qPCR assay but the $\mathrm{CV}$ was much higher $(\mathrm{CV}=0.7740)$ with LOD of $5.61 \times 10^{2} \pm 5.46 \times 10^{2}$ copies $/ \mu \mathrm{L}$ TE Buffer $(\mathrm{Cq}=35.51 \pm$ 1.54) and LOQ of $3.01 \times 10^{2} \pm 2.43 \times 10^{2}$ copies/ $\mu \mathrm{L} \mathrm{TE}$ Buffer $(\mathrm{Cq}=36.78 \pm 2.02)$ (Table 3).

Although the LOD of our HHV-8 ORF73 qPCR assay is 10 to 100 -fold greater than previously reported using this primer set $[6,22]$, scrutinising these previously published data suggests that the LOD given by these authors is not as sensitive as stated. The assay reported by Lallemand et al. [22] displayed a linear standard curve between $10^{6}$ to $10^{1}$ copies, but data for linearity and efficiency were not given: It can be assumed, however, that their assay was not linear above $10^{5}$ copies nor below $10^{2}$ copies, based on the amplification curves shown and the high $\mathrm{CV}$ values reported. Using the same primer and probe set, Asahi-Ozaki et al. [6] displayed a linear relationship from $10^{8}$ to $10^{1}$ copies for both the HHV-8 ORF73 and GAPDH assay, but close examination of their HHV-8 ORF73 amplification curves shows tight replicates down to $10^{2}$ copies: It is unlikely that the assay can yield accurate results below this level with any degree of accuracy. As our amplification curves appear identical to theirs for both assays it is most likely that the sensitivities of both our assays are comparable (Figure 2). As no HHV-8 ORF26 qPCR assay has been published, no such comparisons can be made for this.

The primer/probe sequences of our HHV-8 ORF26 qPCR assay have been used by many laboratories $[23,31]$, but problems with false positives have been reported [32]. Hammock et al. [23] perform their PCR assays with up to 50 cycles in order to detect potentially very low viral loads. While many claims have been made regarding the nature of HHV-8 in lesional tissue based on samples amplifying after many cycles (i.e. $>40$ cycles), it is our experience that the LOD of the HHV-8 ORF26 assay is $5.61 \times 10^{2} \pm 5.46 \times 10^{2}$ copies/ $\mu \mathrm{L}$ TE Buffer $(\mathrm{Cq}=$ $35.51 \pm 1.54$ ) and thus any sample amplifying below this threshold is likely to be a false positive: claims based on data from large cycle numbers are not reliable. This is critical when used clinically, especially in patients with MCD whose disease cannot be easily monitored visually, for if HHV-8 viraemia is not reduced quickly the patient could be dead in 10 months [33].

In order to eliminate the risk of false positives, clinical isolates were tested with both the HHV-8 ORF73 and ORF26 assays [24]: these showed that all KS biopsies (35/35) were HHV-8 positive. The average viral load was
$2.96 \times 10^{5}$ HHV-8 copies $/ \mu \mathrm{L}$ DNA extract (range: $4.37 \times 10^{3}$ to $1.47 \times 10^{6}$ HHV-8 copies/ $\mu \mathrm{L}$ DNA extract), and when normalised equates to an average viral load of $2.44 \times 10^{4}$ HHV- 8 copies $/ 10^{3}$ cells (range: $2.20 \times 10^{2}$ to $7.38 \times 10^{5}$ HHV- 8 copies $/ 10^{3}$ cells). While it was expected that all samples would be PCR positive, because the pathology reports stated the tissues were HHV-8 immunohistochemistry positive, no conclusion can be drawn regarding the viral loads in different stages of KS lesional tissue. Others have claimed to do so [6,31], but it is impossible to normalise to the precise number of virus infected cells in the tissue. These assays are, therefore, best restricted to qualitative detection of virus in tissue samples, although they can give qualitative results in peripheral blood where accurate cell counts can be made. Either way these assays are clearly a valuable tool for detection of HHV-8 infection in a range of clinical samples.

\section{Conclusions}

Two fully optimised, validated, and MIQE compliant HHV-8 assays have been established with excellent sensitivity, specificity and dynamics. These assays can be normalised by cell counts based on GAPDH qPCR results for use in PBMC. These are the first HHV-8 qPCR assays established in Australia and are now available for both research and clinical diagnostics.

\section{Additional files}

\begin{abstract}
Additional file 1: Multiple alignment of the pGEM-T/ORF73 constructs with reference, primers, and probe sequences. Multiple alignment of pGEM-T/ORF73 construct sequence from DH5a E. coli colony \#3 (c-3) and the HHV-8 ORF73 sense (HHV8_73_01.1) and antisense (HHV8_73_02.1) primers and hydrolysis probe (HHV8_73_Pb1) with the HHV-8 ORF73 [GenBank:NC_003409] with periods indicating identical nucleotide bases as the reference sequence.

Additional file 2: Multiple alignment of the pGEM-T/GAPDH constructs with reference, primers, and probe sequences. Multiple alignment of pGEM-T/GAPDH construct sequence from three $\mathrm{DH} 5 \mathrm{a} \mathrm{E}$. coli colonies (C-1 to C-3) and the HHV-8 ORF73 sense (GAPDH_01.1) and anti-sense (GAPDH_02.1) primers and hydrolysis probe (GAPDH_Pb1) with the reference sequence [GenBank:NG_007073.2] with periods indicating identical nucleotide bases as the reference sequence.

Additional file 3: Multiple alignment of the pGEM-T/ORF26 constructs with reference, primers, and probe sequences. Multiple alignment of pGEM-T/ORF26 construct sequence from five DH5a E. coli colonies and the HHV-8 ORF26 sense (HHV8_26_01.1) and anti-sense (HHV8_26_02.1) primers and hydrolysis probe (HHV8_26_Pb1.1) with the HHV-8 ORF73 [GenBank:NC_003409] with periods indicating identical nucleotide bases as the reference sequence.
\end{abstract}

\section{Abbreviations}

BCBL: Body-cavity-based lymphoma; BLASTN: Nucleotide-nucleotide basic local alignment search tool; BSCII: Biological safety cabinet class II;

CAT: Computed Axial Tomography; CLSI: Clinical and Laboratory Standards Institute; Cq: Cycle of quantification; CV: Coefficient of variation; EBV: EpsteinBarr virus; GAPDH: Glyceraldehyde 3-phosphate dehydrogenase; GOI: Gene of interest; GUDSF: Griffith University DNA Sequencing Facility; HAART: Highly active antiretroviral therapy; HCMV: Human cytomegalovirus; HIA-FBS: Heat 
inactivated foetal bovine serum; HHV: Human herpesvirus; HSV: Herpes simplex virus; KS: Kaposi's sarcoma; LOD: Limit of detection; LOQ: Limit of quantification; MCD: Multicentric Castleman's disease; MIQE: Minimum Information for Publication of Quantitative Real-Time PCR Experiments; MRI: Magnetic resonance imaging; NCCLS: National Committee for Clinical Laboratory Standards; NPAAC: National Pathology Accreditation Advisory Council; NTC: No template control; ORF: Open reading frame; PBMC: Peripheral blood mononuclear cells; PCR: Polymerase chain reaction; PEL: Primary effusion lymphoma; PET: Positron emission tomography; QPCR: Quantitative PCR; RSP: Reverse sequencing primer; RtPCR: Real-time $P C R ; T_{M}$ : Annealing temperature; USP: Universal sequencing primer; VIDRL: Victorian Infectious Diseases Reference Laboratory.

\section{Competing interests}

Both authors declare that they have no competing interests.

\section{Authors' contributions}

DJS was responsible for the development of the assays, acquisition and interpretation of data, and drafting the manuscript. NWJ initiated the HHV-8 research program, and contributed to manuscript revision and final presentation. All authors read and approved the final manuscript.

\section{Acknowledgements}

This study was supported by Pathology Queensland's Study Education and Research Trust Fund (SERTF reference number: 1932_WeinsteinS). We thank Dr Jennifer Webster-Cyriaque (Dental Research Center, University of North Carolina, USA) for providing the BCBL-1 cell line, and Dr. Jackie Kattenbelt, (Sir Albert Sakzewski Virus Research Center, Royal Children's Hospital, Brisbane, Queensland, Australia) for the DH5a Escherichia coli. The viral control samples for HCMV, VZV, and HHV-6 were provided by Professor William Rawlinson, AM (SEALS Prince of Wales Hospital, New South Wales, Australia); HSV-1 and 2 by Wen bin Chen (Department of Virology, RBWH, Queensland, Australia), EBV by Professor Denis Moss (QIMR, Queensland, Australia); and HHV-7 by Professor Yasuko Mori (Kobe University, Japan).

\section{Author details}

${ }^{1}$ School of Dentistry and Oral Health, Griffith University, Queensland, Australia. ${ }^{2}$ Molecular Basis of Disease Research Program, Griffith Health Institute, Griffith University, Queensland, Australia. ${ }^{3}$ Population \& Social Health Research Program, Griffith Health Institute, Griffith University, Queensland, Australia.

Received: 17 February 2012 Accepted: 28 June 2012

Published: 11 September 2012

\section{References}

1. Grulich AE, Cunningham P, Munier ML, Prestage G, Amin J, Ringland C, Whitby D, Kippax S, Kaldor JM, Rawlinson W: Sexual behaviour and human herpesvirus 8 infection in homosexual men in Australia. Sex Health 2005, 2(1):13-18.

2. Grulich AE, Olsen SJ, Luo K, Hendry O, Cunningham P, Cooper DA, Gao SJ, Chang Y, Moore PS, Kaldor JM: Kaposi's sarcoma-associated herpesvirus: a sexually transmissible infection? J Acquir Immune Defic Syndr Hum Retrovirol 1999, 20(4):387-393.

3. Mclver CJ, Jacques CF, Chow SS, Munro SC, Scott GM, Roberts JA, Craig ME, Rawlinson WD: Development of multiplex PCRs for detection of common viral pathogens and agents of congenital infections. J Clin Microbiol 2005, 43(10):5102-5110.

4. Senanayake S, Kelly J, Lloyd A, Waliuzzaman Z, Goldstein D, Rawlinson W: Multicentric Castleman's disease treated with antivirals and immunosuppressants. J Med Virol 2003, 71(3):399-403.

5. Meng YX, Spira TJ, Bhat GJ, Birch CJ, Druce JD, Edlin BR, Edwards R, Gunthel C, Newton R, Stamey FR, et al: Individuals from North America, Australasia, and Africa are infected with four different genotypes of human herpesvirus 8. Virology 1999, 261(1):106-119.

6. Asahi-Ozaki Y, Sato Y, Kanno T, Sata T, Katano H: Quantitative analysis of Kaposi sarcoma-associated herpesvirus (KSHV) in KSHV-associated diseases. J Infect Dis 2006, 193(6):773-782.

7. Taylor MM, Chohan B, Lavreys L, Hassan W, Huang ML, Corey L, Ashley Morrow R, Richardson BA, Mandaliya K, Ndinya-Achola J, et al: Shedding of human herpesvirus 8 in oral and genital secretions from HIV-1-seropositive and -seronegative Kenyan women. J Infect Dis 2004, 190(3):484-488.

8. Mbulaiteye SM, Pfeiffer RM, Engels EA, Marshall V, Bakaki PM, Owor AM, Ndugwa CM, Katongole-Mbidde E, Goedert JJ, Biggar RJ, et al: Detection of kaposi sarcoma-associated herpesvirus DNA in saliva and buffy-coat samples from children with sickle cell disease in Uganda. J Infect Dis 2004, 190(8):1382-1386.

9. Dallas-Yang Q, Jiang G, Sladek FM: Avoiding false positives in colony PCR. Biotechniques 1998, 24(4):580-582.

10. NPAAC: Laboratory Accreditation Standards and Guidelines for Nucleic Acid Detection and Analysis. Canberra: National Pathology Accreditation Advisory Council; 2006.

11. Hall TA: Bioedit: a user-friendly biological sequence alignment editor and analysis program for Windows 95/98/NT. Nucleic Acids Symp 1999, 78:7863-7866

12. Bustin SA, Benes V, Garson JA, Hellemans J, Huggett J, Kubista M, Mueller R, Nolan T, Pfaffl MW, Shipley GL, et al: The MIQE guidelines: minimum information for publication of quantitative real-time PCR experiments. Clin Chem 2009, 55(4):611-622.

13. CLSI MM3-A2: Molecular Diagnostic Methods for Infectious Diseases; Approved Guidelines. Secondth edition. Wayne, Pennsylvania: Clincal and Laboratory Standards Institute; 2006.

14. NCCLS MM3-A2: Quantitative Molecular Methods for Infectious Diseases: Approved Guideline. Wayne, Pennsylvania USA: NCCLS; 2003.

15. Mikeska T, Dobrovic A: Validation of a primer optimisation matrix to improve the performance of reverse transcription - quantitative realtime PCR assays. BMC Res Notes 2009, 2:112.

16. Stratagene: Introduction to Quantitative PCR (Methods and Application Guide). USA: Agilent Technologies Inc; 2010.

17. NCCLS EP6-A: Evaluation of the Linearity of Quantitative Measurement Procedures: A Statistical Approach; Approved Guidelines. Wayne, Pennsylvaina: NCCLS; 2003.

18. Tholen D: Evaluation of linearity using the newly approved NCCLS EP6-A protocol. Clin Lab News 2004, 30:10-12.

19. Dimech W, Bowden DS, Brestovac B, Byron K, James G, Jardine D, Sloots T, Dax EM: Validation of assembled nucleic acid-based tests in diagnostic microbiology laboratories. Pathology 2004, 36(1):45-50.

20. Backhouse J, Caon A, Dimech W, Edwards I, Field P, Heron L, Robertson P, Sampson I, Tinniswood R: Proposed general protocol for study of serological diagnostic reagents. Aust Microbiol 1994, 15:37-45.

21. NPAAC: Requirements for the Development and use of In-house in Vitro Diagnostic Devices (IVDs). Canberra: National Pathology Accreditation Advisory Council; 2007.

22. Lallemand F, Desire N, Rozenbaum W, Nicolas JC, Marechal V: Quantitative analysis of human herpesvirus 8 viral load using a real-time PCR assay. J Clin Microbio/ 2000, 38(4):1404-1408

23. Hammock L, Reisenauer A, Wang W, Cohen C, Birdsong G, Folpe AL: Latencyassociated nuclear antigen expression and human herpesvirus-8 polymerase chain reaction in the evaluation of Kaposi sarcoma and other vascular tumors in HIV-positive patients. Mod Pathol 2005, 18(4):463-468.

24. Whiley DM, Lambert SB, Bialasiewicz S, Goire N, Nissen MD, Sloots TP: False-negative results in nucleic acid amplification tests-do we need to routinely use two genetic targets in all assays to overcome problems caused by sequence variation? Crit Rev Microbiol 2008, 34(2):71-76.

25. Ratcliff RM, Chang G, Kok T, Sloots TP: Molecular diagnosis of medical viruses. Curr Issues Mol Biol 2007, 9(2):87-102.

26. Aslanzadeh J: Preventing PCR amplification carryover contamination in a clinical laboratory. Ann Clin Lab Sci 2004, 34(4):389-396.

27. Lo YM, Chan KC: Setting up a polymerase chain reaction laboratory. Methods Mol Biol 2006, 336:11-18,

28. Whiley DM, Faux CE, Bialasiewicz S, Gould AR, Lambert SB, Nissen MD, Sloots TP: A simple approach for preparing real-time PCR positive reaction controls for rare or emerging viruses. J Clin Virol 2010, 48(3):193-197.

29. Smith G, Smith I, Harrower B, Warrilow D, Bletchly C: A simple method for preparing synthetic controls for conventional and real-time PCR for the identification of endemic and exotic disease agents. J Virol Methods 2006, 135(2):229-234.

30. Renne R, Zhong W, Herndier B, McGrath M, Abbey N, Kedes D, Ganem D: Lytic growth of Kaposi's sarcoma-associated herpesvirus (human herpesvirus 8) in culture. Nat Med 1996, 2(3):342-346. 
31. Pak F, Mwakigonja AR, Kokhaei P, Hosseinzadeh N, Pyakurel P, Kaaya E, Bogdanovic G, Selivanova G, Biberfeld P: Kaposi's sarcoma herpesvirus load in biopsies of cutaneous and oral Kaposi's sarcoma lesions. Eur J Cancer 2007, 43(12):1877-1882.

32. Pellett PE, Spira TJ, Bagasra O, Boshoff C, Corey L, de Lellis L, Huang ML, Lin $J C$, Matthews S, Monini P, et al: Multicenter comparison of PCR assays for detection of human herpesvirus 8 DNA in semen. J Clin Microbiol 1999, 37(5):1298-1301.

33. Shahidi H, Myers JL, Kvale PA: Castleman's disease. Mayo Clin Proc 1995, 70 (10):969-977.

doi:10.1186/1471-2334-12-210

Cite this article as: Speicher and Johnson: Detection of human

herpesvirus 8 by quantitative polymerase chain reaction: development and standardisation of methods. BMC Infectious Diseases 2012 12:210.

\section{Submit your next manuscript to BioMed Central and take full advantage of:}

- Convenient online submission

- Thorough peer review

- No space constraints or color figure charges

- Immediate publication on acceptance

- Inclusion in PubMed, CAS, Scopus and Google Scholar

- Research which is freely available for redistribution 